effort best described, I think, by the word $s u b$ tile.

Are we at present prepared to base reasonable, common-sense indications for operation upon any such refined mental processes as I have here indicated? Ought not common-sense advice to be based upon common-sense brain work, rather than upon an intellectual endeavor so delicate as to require special effort in the selection of a word adequate to describe that delicacy?

I am inclined to think that it is just such subtile processes of delicate reasoning and refined deduction that makes for the highest expression of successful professional endeavor, and that the time has come for the substitution of these more intellectual methods of diagnosis for so coarse and indefensible a line of procedure as the exploratory laparotomy.

Finally, a certain important question may well be discussed here, for it is a question which affects vitally every patient, both medical and surgical.

Shall we wait for pathological changes of serious disease to become so characteristic that diagnosis is unmistakable? Shall the trend of medical and surgical thought be toward accuracy at the expense of safety? Shall the disease come to the surgeon, or the surgeon go to the disease? Shall the lesion prevail until the surgeon perforce strikes a blow, or shall the surgeon assault, overwhelm and destroy the lesion at its very inception? Shall we take that initiative so important and so favorable in matters of war, or shall we rest on the defensive?

The answer is simple, it seems to me. With our utmost endeavor we must make our attack at the earliest possible moment after we have with reasonable accuracy located the enemy, and ascertained his resources.

We must study disease as carefully as in war we study the enemy. We cannot hope to succeed in resisting assault if we rest in fancied security while a Stonewall Jackson steals upon and overwhelms us. Nor can we hope ever to attain success if we fail to study, to their minutest details, the strength, mobility, commissariat, officering and enthusiasm of the enemy, and particularly the field of operations. We must in diseases, as well as in war, prepare for our campaign by long, persistent, arduous study; and we cannot hope to do our duty by our patient if, when the actual conflict opens, we say: "Here is a patient who is said to have gallstones. We have never seen her before. We may speculate as long as we please about her trouble, but we shall never know what it is until we operate. Let us explore and find out."

As well might the commander say, "The enemy is said to be over there. We cannot do anything until we know for sure. Let us attack and find out." And without forethought he blindly attacks and finds himself entrapped, outflanked and defeated.

Until the surgeon has taken all reasonable and safe precautions to make as positive a diagnosis as can be made, he has no right to operate for gallstones or any other lesion.
When he fails thus to make the diagnosis, and the error means increased suffering and ill-health, or death and disability, he must resort to an exploration, and he can then with a clear conscience do so.

\section{THE PLACING OUT OF HIGH-GRADE IMBECILE} GIRLS:*

BY WILLIAM N. BULLARD, M.D.

I DESIRE to-night to say a few words in regard to the placing out or placing in families of highgrade imbecile girls. This is now done both intentionally and ignorantly by private charitable societies, and also by the state.

In May last, I had the honor to present before this society a paper ${ }^{1}$ on this class of defectives and to state the difficulties in the detection and diagnosis of such cases and in the provision of suitable care and protection for them. This latter provision has since been furnished to a greater degree than previously by Dr. Fernald, at the School for the Feeble-Minded at Waverley.

While up to the present time it has, on account of the difficulties above mentioned, been extremely hard to avoid the placing out of such girls, we have now reached a position where it is well for us to consider whether this placing out in families is a wise or justifiable procedure, or whether some more suitable provision for them cannot be made.

I am personally convinced that such girls should only be placed out in case of necessity. when no other provision is possible, and then under the strictest guard.

This class of girls is absolutely untrustworthy. Many of them lie and steal, and truthfulness is not in them. But much more important even than this for the welfare of the community is the fact that many of them have strong sexual proclivities. They run after the male sex without shame and make opportunities for sexual intercourse readily, cunningly and frequently. Unless watched absolutely every moment, such girls are apt to escape from the best households and ruin themselves and others. They have apparently no normal conscience in that direction and neither have nor desire to have any control over their sexual impulses.

Their placing out should never be allowed when it is possible to find a suitable alternative. The chief reason for this is the one above stated, that such girls almost inevitably, no matter by what precautions they are surrounded, on account of mental deficiency, are either unable to protect themselves from the demands of others or are indifferent about doing so. A considerable proportion of them seek occasion and opportunity for that which results in the acquisition and giving of venereal disease and the production of illegitimate and often diseased offspring.

CAse I. This girl was born in May, 1886, of French-Canadian parents. The father, though not * Read before the Boston Society of Psychiatry and Neurology, April 15, 1909 . 1908 . 
strictly temperate, is a steady worker, and the mother is said to be a decent, respectable woman. The patient has one sister, who is feeble-minded.

In September, 1901, when somewhat more than fifteen years old, the patient was committed to the State Industrial School for stubbornness. She was kept at the school until November, 1902, thirteen months, and was then returned to her home because she could not learn and it was thought that she could not be placed out. At first on her return she was be- lieved to be doing well, although dull at work. In the following June (1903), however, it was found that she had fallen very low. She had become the "prey of everybody" and had syphilis. She was sent at once to the State Hospital at Tewksbury, and was kept there until April, 1904 (ten months), after which she was returned to the school at Lancaster. She was now retained in the school on account of syphilis for about two years and then placed with a good woman in Boston. This woman, whom we will call Mrs. A., watched her very carefully and was very strict. She said that she needed constant watching, and in November, 1906, a few months after she received her, she stated that she was a great care and she could not keep her. She wanted to run after men.

Patient was now placed in an excellent place on a small farm where the only man in the house was very old and where the woman was accustomed to caring for the feeble-minded. Here she was kept safe for the few months before she became of age (May, 1907). All control over these patients by the State Industrial School ceases when they become of age. Consequently this woman was discharged from the care of the state and was sent home.

Her subsequent history forms the moral of this story. She went home after her discharge, May, 1907, but soon quarreled with her family because they were too strict, and went to another city. In October, 1907, she was again in Boston, now chambermaid in a bad house. She soon became the mistress of a man for a time, but was finally turned out on the street by him, and in January, 1909, was arrested for nightwalking and soliciting.

This case needs little comment. The patient is of slightly lower grade than some of those whom we are discussing. She was thought by some of the officers of the State Industrial School to be distinctly feeble-minded at the time of her discharge, and yet not sufficiently so to be sent to the School for the Feeble-Minded, in view of their attitude at that time in regard to these cases.

Case II. Born November, 1887. Father very poor and ignorant, but decent. Mother weak-minded; passive; ordered about by son five years old. It is stated that the whole family, except one boy, was below grade mentally.

Patient was committed to the State Industrial School, May, 1904, when sixteen and a half years old, with the following history: She had been unchaste for three years; had probably frequented bad houses. Her mental condition is such that she can be influenced by any one she meets. She runs away from home and stays away one or two days.

After having been nearly two years at the School, this patient was placed out in March, 1906. Was returned to the School in June because she had stayed out two nights, and been unchaste. From this experience she had an illegitimate child. (She had been placed in a good family in a country town. One day she went out on the street and accosted the first boys she met, who were perfect strangers to her, and went away with them and did not return until midnight. The next day she got out again with the boys and stayed till 3 A.M. She admitted unchastity readily. She never knew the names of the boys.)

In February, 1907, was confined at Tewksbury and baby born.

April 30, 1907. Again placed out in another town. The report there is that she takes no responsibility for her baby. Was willing at this time to spend all her earnings for it and was fond of it, but gave it bread and sour milk when four weeks old. Was unable to care for it on account of her mental deficiency.

At this place would go out without permission to visit the neighbors and stole things which she would give away. Said man of the family made indecent proposals to her and was at once removed. (To make this accusation is known among these girls as a sure way to secure immediate removal from any place they dislike or are tired of.)

In July, 1907, was put in a third place. While there, in September, her baby died of cholera infantum. Patient was indifferent. At this time she wrote innumerable letters to different people. The family with whom she lived could not trust her. They decided that they could not stand her and would not keep her and she was put in a fourth place. She would wander off and talk to any young man.

February, 1908, ran away. Two days later was placed in temporary home, and in March, 1908, was sent to the Massachusetts School for the Feeble-Minded at Waverley. class.

Résumé. Bad inheritance. Early prostitution. In spite of two years' training at the State Industrial School, when placed in a quiet town in a good family she escapes, accosts the first boys she meets and falls their victim. Has a baby whose necessities and requirements she cannot comprehend and whom she is unable to care for properly. Steals without cause. Still seeks after men and finally, having been placed in four different families in four different towns, in each of which she may or may not have spread disease, she is finally, much too late, committed to the School for the Feeble-Minded, where she undoubtedly should have been placed as a child.

CASE III. The father of this patient is unknown. The mother was married twice, but this is an illegitimate child, born between the marriages. The mother has a bad reputation and is undoubtedly immoral. She is also mentally deficient. One brother of the patient is mentally wanting, "half-baked." One sister is at the State Industrial School at Lancaster. The patient was born in July, 1890; therefore is now nineteen. She was committed to the school in May, 1905, as dissolute, lewd and immoral.

The girl was first placed out in October, 1906, in a town near Boston, with intelligent and educated people, the head of the family being a lawyer. In November, Mrs. A., the lady of the house, wrote that she did not wish to keep her as she was not competent and had no head, but she was finally induced to keep her as there was no other good place to send her.

March, 1907, Mrs. A. says that she is a good housekeeper. She has to be guarded carefully. Is very fond of boys.

August, 1907, Mrs. A. states: "Very untruthful. Has to be watched all the time and ruled with an iron hand. Decidedly feeble-minded."

In this place the girl was as safe as she could possibly be with an educated woman who had had some experience with such cases, but none the less the patient was 
visited by a young man in the house one evening when Mrs. A. was away. This young man was of good family, but rather deficient.

While here she hid her clothes and declared that they were lost because she thought that she could in this way obtain new ones.

She gave a silk waist to a fortune-teller and telephoned herself to the police that the woman had stolen it, and made great trouble in her own house in consequence.

In July, 1908, Mrs. A. says that she cannot guarantee to keep her safe and she was removed to a family in a city near Boston, not near her former residence.

At this time she corresponded with a boy, receiving the most vicious and obscene letters without objection.

She showed while here " marked criminal tendencies." She lied and stole. Mrs. B., the woman with whom she now lived, felt that she was a danger to herself and to the neighborhood. - She was caught talking to one man and said another was her cousin.

On the other hand, she took a great deal of pride in her kitchen, laundry and bed-room, and kept everything in perfect order.

She was finally committed to the Massachusetts School for the Feeble-Minded at Waverley.

CASE IV. Father a hard drinker; brutal; fined for beating his child. Mother immoral; has been in Sherborn Prison; deserted her family. One sister married, bad ; two sisters committed to Lancaster.

Patient was born July, 1889. She was committed to the State School for larceny, December, 1904.

Placed on probation July, 1906. Placed with a family in a city near Boston. It is reported that she does well, but is childish. October, 1906, her work is unsatisfactory. She shows no interest in it. Her conduct is otherwise good. Reported "very good with children." November, 1906, was removed because patient did not like the place, and wanted to take care of children. Was placed in Cambridge Nov. 9; removed Nov. 22 because the woman was afraid to leave her children with her. She was not nice with them and taught them bad words and tricks. Is childish. Was now placed in another family in a country place. This family was thought to be a specially good one. January, 1907, they report that she acts like an overgrown child. March, 1907, happy; says that she has a fine place. Nevertheless, during the winter she has not been satisfactory. Miss C. had been much away and Mrs. C. could not manage her. July, 1907, extremely saucy.

November, 1907, found to be pregnant. Charged various persons with being the cause; among others, members of the family she was with. Nov. 25, removed to fourth place. Tells ridiculous lies; is stubborn at times. Sometimes her mind seems to be a blank.

February, 1908, removed to fifth place, as she needed more care on account of her condition. While here, being at this time eight months pregnant, she tried skating with roller skates, which she had never put on before and fell and broke her ankle. The leg was put in a plaster cast, but when this was removed in March, it was found to be ununited. She has never complained of pain from it.

Baby was born March 30 at the Lying-In Hospital. She did not complain of labor pains. She did not seem to comprehend or care about her baby.

July, 1908. She is now with a very good woman who forces her to care for her baby. She cannot be trusted to look out for it unless under supervision. She is now inclined towards men and has to be constantly watched. Is filthy; will not use toilet room. Cannot be trusted with the gas.
August, 1908. Papers for the Massachusetts School for the Feeble-Minded signed.

November, 1908. Committed to the School for the Feeble-Minded after a contest with the relatives before the court.

The patient was markedly feeble-minded. She was reported childish at each place where she lived. After pregnancy her mental condition became worse. She showed much blunting to the sense of pain. She was unable to care for her child. In spite of her obvious condition, her commitment to Waverley was opposed in court by her father and her sister, who wished to take charge of her themselves. (I am informed that the judge doubted about the family but was finally convinced when he found that the father had left a younger girl, thirteen years old, alone in the house with a dissolute negro.)

Case V. Born Aug. 23, 1891. French Canadian. Committed Aug. 18, 1905, as a stubborn child.

Patient has been in some home of detention for larceny; had also been in Oaklong Home several months previous to being committed to Lancaster. Used to stay out at night until eleven o'clock ; is thought to be unchaste but did not frequent houses of ill-repute. At time of admission to the State Industrial School it was reported that she had been out of school one year; could not read or write. She had worked in a mill and also done housework. Patient states that her father has consumption and that her mother has had epilepsy for fifteen years. Says mother had incipient phthisis in July, 1891. The house surroundings are reported as being poor. The father works steadily; is a weaver; is kind to patient; drinks. $\mathrm{He}$ has not lived with his wife for some time. Left the place where he was living two months ago. His present address is unknown. The mother seems to have a bad reputation; does not drink; weaver. Has had twenty-two children, five of whom are living. Until recently, she lived with a $\mathrm{Mr}$. $\mathrm{H}$. and took four men to board. She got into debt; " skipped in the night, her boarders going with her." Since then has moved three times. Present whereabouts are unknown. No one can say anything good of her.

Miss Dewson, probation officer for the State Industrial School, reports: Patient has had five chances in eight months; has completely spoiled three good Catholic homes, so that they will not consider our girls again. It has been necessary to visit her constantly. She has times when it is impossible to do anything to hold her. She goes out at night; once was determined to walk to Boston from Salem along the track. They had to get a policeman to prevent her. At times she does not want to work; cannot seem to concentrate her mind and is not able to do anything of value. She is sorry after these attacks are over; says that she cannot help them. Between times she can do very well and rather enjoys some kinds of work. She can show an interest in one thing for a short time only. She is very childish; likes to sit on the floor playing games with the children; would like a doll. She lies constantly; is forgetful; breaks and destroys things; is dirty about her work; needs constant supervision. She left the oil running from a five-gallon can after filling the lamps. At one place had a carving knife in the drawer. The woman of the house thought that she would have used it if aroused.

Matron's report, State Industrial School: "Patient does not read and write well. At times she can comprehend what she reads much better than at others. She can do only simple examples in numbers; does not understand division. At times desires to do well in her work, but does not seem able to. Sews very well one day; another seems unable to. She does housework 
fairly well but is untidy. Does not iron well. Needs constant supervision. She is untidy about her person; dishonest; and will lie."

This patient was placed out for about a year and was then returned to the school. She had stolen certain things and the stolen articles were found in her possession.

When seen by me in November, 1908, she said that she did not know why she took the things but she thought they were pretty. She says that it is not honest to steal, but does not seem to have any clear idea why she should be honest except that she is told to be so.

She is thought to be mentally deteriorating.

Case VI. Father was cruel and beat her if she did not bring him money; forced her to have connection with Chinese men in order to get money. One brother is, or has been, in Charlestown prison. One brother below par mentally.

She was committed to the State Industrial School in March, 1904, when about thirteen and a half years old on account of the condition of affairs at home. She was said in court to be feeble-minded.

Has a mild, gentle nature; does what any one tells her. No sexual proclivities.

In June, 1905, went to work for a woman who lived just across the road from the School, but slept at the School. Continued this until May, 1906.

In June, 1906, was placed out. Her work was light. Incapable of doing much. Finally said she was tired and in July, 1907, went back to the School. Was placed in a second place September, 1907, and stayed until October, 1908. There she got on " pretty well " but was very incapable. Was kind to the children.

Committed to Waverely.

Very easily over-excited. Was given a dress-suit case which she wanted, for Christmas, and she was so pleased and excited that she had to go to bed for two days and then to the Convalescent Home.

These cases are sufficient to demonstrate the results of the placing out of high-grade imbecile girls. These girls, instead of being placed in families where they breed disease and crime, should, as soon as their condition is recognized, be placed in an institution fitted to take care of them. By doing this we shall be able to save the community from danger.

While it is not necessary that every high-grade imbecile girl should be placed in an institution, but only those who have no suitable homes where they can be safely guarded, yet even where the home is good, much evil and sorrow may be avoided if such girls are placed under care early, before any serious mischief has occurred.

Although the two reasons which far outweigh all others against the placing out of these girls are,

(1) The danger that they spread crime and disease through the community;

(2) The risk of their own degradation, disease and sin. The deterioration and destruction of a human soul;

there are also other secondary reasons which render this placing out unwise. These are:

(3) The waste of money to the state. It is better financially for the state to care for one woman during the whole of her maturity rather than to care for her at intervals, at Sherborn and elsewhere, and to be obliged to support one or is yet time. more illegitimate children, not to mention the cost of such disease as she may spread.

(4) It is waste of time and of energy for the societies, public or private, to attempt to care for this class. While some examples may under special circumstances be guarded for a time, the large majority fall sooner or later and usually fall far. We have a right to ask that the time and energy wasted in such unsatisfactory and unprofitable work be better spent.

Such cases as I have related are typical of a comparatively large class of girls. We have until lately been unable to recognize the members of this class, and even now the average physician would find great difficulty in many cases. Many of these girls cannot be placed in this class without thorough knowledge not only of their previou history, but of their present capacities, - intellectual, practical and moral. These capacities cannot be tested in the physician's office. An acquaintance with the general life of the girl, often over a considerable period, is in many cases absolutely required.

If in a given case we are able to form a definite opinion and it is settled that the girl is a mental defective of this kind, we have hitherto been met by certain practical difficulties.

In the first place, there has been no definite provision for the permanent care of this class by the state. It is scarcely more than a year that it has been possible to place them, unless as exceptions and more or less under protest, in any suitable public institution.

In the second place, the endeavors to get these cases properly committed have been blocked, and the work of saving these girls and the community has been impeded, by the lack of special knowledge and by the conservatism of the courts. It has been necessary not only to find a place where these girls could be cared for properly, but after the place had been found and the institution was ready, contrary to its own apparent interest, for the sake of duty and charity, to receive these girls, the further obstacles caused by the attitude of certain judges had to be overcome. This attitude not only raised obstacles to the commitment of these patients, but also rendered the institution which received them more liable to annoying lawsuits later from evil or ignorant relatives.

That these girls spread crime and disease Though the community is very plain to any one who follows their histories. They are often sources of corruption to the neighborhood. They are apt to breed mental defectives, feeble-minded children and moral imbeciles.

It is a grave moral question also how far it is ustifiable to place these girls in good homes in which they are apt to breed disease and perchance to cause moral injury or corruption to members of the family. They should never be allowed to care for or have charge of children. Aside from their irresponsibility, they may teach evil.

Let us, then, strive to recognize this class of the NEJM Archive. Copyright $\odot 2010$ Massachusetts Medical Society. 